Jan Dzięgielewski

Warszawa

\title{
Dzieło dziejopisarskie przedmiotem debaty sejmów w czasie trzeciego bezkrólewia*
}

Spory polityczne wywoływane z powodu książek historycznych zdarzały się w przeszłości i zdarzają się obecnie. W Rzeczypospolitej Obojga Narodów były jednak czymś niesłychanie rzadkim ${ }^{1}$. Kilka mandatów królewskich zakazujących rozpowszechniania takich dzieł ze względu na to, iż ich treść godziła w dobre imię przodków bądź członków innych dynastii, szerszych i głośniejszych sprzeciwów nie wywoływały. Podobnie jak i uchwały sejmików zawierających żądania konfiskaty druków uwłaczających sławie zasłużonych dla Rzeczypospolitej rodów. Sprawy związane z edycjami statutów, konstytucji sejmowych czy też ksiag o treści religijnej budziły wówczas znacznie więcej kontrowersji, co uwidaczniało się również w debatach publicznych ${ }^{2}$.

W tej sytuacji za wydarzenie wyjątkowe należy uznać batalię toczącą się podczas bezkrólewia po śmierci króla Stefana Batorego o dzieło Reinholda Heidensteina De bello Moschovitico commentariorum libri VI. O wyjątkowości tych wydarzeń świadczy zaangażowanie w nie głównych postaci ówczesnego życia, ale przede wszystkim czas, w którym się rozegrały. Spór rozpoczął się na sejmie konwokacyjnym. Po zakończeniu konwokacji angażował interreksa i wielu senatorów, a zwłaszcza kanclerza i hetmana wielkiego koronnego Jana Zamoyskiego. Wreszcie wracano do tej sprawy podczas sejmu elekcyjnego.

* Poszerzona anglojęzyczna wersja tego artykułu ukazała się tomie Book versus Power: Studies in the Relations between Politics and Culture in Polish History, J. Soszyński, A. Chamera-Nowak (eds.), editorial assistance D. Embree (Polish Studies - Transdisciplinary Perspectives, 15), Frankfurt am Main 2015, s. 105-116.

1 Zob. P. Buchwald-Pelcowa, Cenzura $w$ dawnej Polsce. Między prasq drukarska a stosem, Warszawa 1997, s. 58-59.

2 Tamże, s. 43-48, 53-56, 60-69. 
Było oczywiste, że siły opozycyjne wobec polityki zmarłego króla i wspierającego go układu politycznego, a zwłaszcza osobiści wrogowie jego najbliższego współpracownika, wykorzystają okres bezkrólewia, aby doprowadzić do zmiany sytuacji własnej oraz kierunków polityki państwa. Największe szanse dawałoby im wprowadzenie na tron popieranego przez siebie kandydata. Ale poprawę pozycji, a zwłaszcza naprawę tego, „co się skaziło”, jeśliby to uczestnicy sejmu elekcyjnego uznali za egzorbitancję, można by było uzyskać nawet w przypadku braku sukcesu w walce wyborczej, tak jak miało to miejsce podczas pierwszego bezkrólewia, kiedy to przeciwnicy kandydatury Walezego zostali pozyskani do zaaprobowania jego elekcji za zamieszczenie postulowanych przez nich rozwiązań w Artykułach henrykowskich. Bowiem według obowiązującej procedury wybór władcy powinien nastapić za zgodą biorących udział w akcie elekcji.

Bezkrólewia, jakkolwiek od 1573 r. istniał specjalny system władzy przewidziany na czas ich trwania ${ }^{3}$, były jednak okresami, w których zdolność skutecznego funkcjonowania Rzeczypospolitej pozostawała osłabiona, co wzmagało niepokój mieszkańców o bezpieczeństwo państwa $\mathrm{i}$ ich własne. Brak monarchy skłaniał do poczuwania się do większej odpowiedzialności przez szlachtę, najbardziej znacząca siłę polityczną w kraju. Mobilizował też ją do nadzwyczajnej aktywności. Na własny koszt brała udział w kilku zgromadzeniach stanowych: partykularnych, prowincjonalnych i ogólnopaństwowych, podejmując decyzje mające zapewnić poszczególnym ziemiom i całej Rzeczypospolitej obronę oraz utrzymanie ładu wewnętrznego, w tym bardzo istotnego dla tamtej epoki - pokoju wyznaniowego. W czasie tych zgromadzeń prowadzona też była debata dokonująca oceny minionego panowania i ustalająca potrzeby, które wymagają realizacji. Wreszcie był to okres kampanii wyborczej, niesłychanie istotnej, gdyż miała doprowadzić do elekcji monarchy.

Bardzo pobieżne przypomnienie istoty bezkrólewia, zadań stojących przed obywatelami, nadziei i niepokojów z tym okresem związanych jeszcze bardziej uwypukla wyjątkowość wydarzenia, jakim była walka o dzieło R. Heidensteina w 1587 r.

Nie są znane źródła, które pozwoliłby stwierdzić intencje, jakimi kierowali się przywódcy ugrupowania skupiającego stronników Zborowskich i Andrzeja Górki, gdy - obok ścięcia Samuela Zborowskiego i ska-

3 J. Dzięgielewski, Sejmy elekcyjne, elektorzy, elekcje. 1573-1674, Pułtusk 2003, s. $60-62$. 
zania na kary główne jego brata Krzysztofa - jako przejaw krzywd rodu, a jednocześnie naruszenia prawa pospolitego i wolności szlacheckich wymieniali też edycję komentarzy R. Heidensteina, domagając się, aby już sejm konwokacyjny dokonał restytucji Krzysztofa i nakazał konfiskatę księgi. Analiza jej treści nie daje podstaw do twierdzenia, iż znajdują się w niej informację bądź oceny, które mogłyby mieć negatywny wpływ na wizerunek rodu panów ze Zborowa. $Z$ innego więc powodu zamieścili oni sprawę owego druku wśród najistotniejszych swych postulatów i uporczywie żądali, aby senatorowie i posłowie uczestniczący w sejmie konwokacyjnym uznali je za egzorbitancje o charakterze publicznym i moca postanowień już tego sejmu to, na co prawo pozwala, naprawili. Przyznawali konwokacji między innymi uprawnienie do „wywołania” z Rzeczypospolitej De bello Moschovitico...

Sejm konwokacyjny uprawnień takich nie posiadał i dlatego postanowień pożądanych przez Zborowskich nie podjął. Zdecydowana większość jego uczestników podzielała jednak przekonanie, że minione panowanie nie było wolne od faktów dokonywanych ,przeciwko prawu, przywilejom i swobodom"4. W uchwalonym akcie konfederacji generalnej znalazł się w związku z tym zapis, który uznawał sejm elekcyjny za organ władny do orzekania, czy sprawy przedstawiane jako egzorbitancje takimi $\mathrm{w}$ istocie były. Zawierał też zobowiązanie nieprzystępowania do aktu elekcji, ,ażby wszystkie vulnera Reipublicae et privatorum excessus et gravamina, exorbitantiae, któryby się słusznie pokazać mogły, authoritate Conventus Electionis zniesione, y w swą klubę wprawione były"5.

Uchwał konwokacji nie podpisali dawni regaliści, których niekwestionowanym przywódca w Koronie był Jan Zamoyski, nieobecny na obradach tego sejmu ${ }^{6}$. Ale nie chcieli ich też podpisać Jan i Andrzej Zborowscy, co musiało budzić niepokój o stan bezpieczeństwa wewnętrznego w czasie obrad sejmu elekcyjnego. Dlatego interreks wraz z częścią senatorów niezwiązanych $\mathrm{z}$ antagonistycznymi ugrupowaniami silniejszymi więziami podjął starania zmierzające do złagodzenia konfliktu między głównym beneficjentem poprzedniego panowania, czyli Zamoyskim, i rodem uważającym się za jego główną ofiarę. Spisano warunki, na jakich powinno dojść do porozumienia. Uwzględniały one część po-

\footnotetext{
${ }_{4}$ Zob. A. Pieńkowska, Zjazdy i sejmy z okresu bezkrólewia po śmierci Stefana Batorego, Pultusk 2010, s. 174-184.

5 Volumina Legum, t. II, Petersburg 1859, s.228-229

6 Tym bardziej że i inne uchwały, a przede wszystkim wyłączenie spod władzy hetmana wielkiego koronnego dowódców dokonanych przez sejmiki zaciagów, miały osłabić pozycję Zamoyskiego.
} 
stulatów Zborowskich, w tym również zgodę kanclerza na „wywołanie z kraju" księgi R. Heidensteina ${ }^{7}$.

Zamoyski porozumienie na takich warunkach odrzucił, nie zamierzał bowiem iść na jakiekolwiek ustępstwa polityczne, a tym bardziej na jakiekolwiek korekty ustrojowe umożliwiające bardziej skuteczny nadzór stanów nad sprawującymi rządy. Dążył jedynie do wprowadzenia na tron własnego kandydata i sprawowania de facto władzy przez duet rządzący, czyli króla i „pierwszego ministra”, chociaż inne już miały być ich relacje wewnętrzne niż w czasach Batorego. Najbardziej zdolny i skuteczny ze staropolskich polityków doskonale jednak zdawał sprawę, że odrzucając mediację, która miała służyć zgodzie, czyli stanowi stosunków wewnętrznych idealizowanemu przez szlachtę, będzie musiał umiejętnie to uzasadnić. Co też uczynił, a jego Odpowiedź...8 znajdująca się w zbiorach wielu bibliotek pod różnymi tytułami, jest propagandowym majstersztykiem.

Kwestii nas interesującej poświęcił kanclerz ok. 1/5 całego tekstu odpowiedzi. Najpierw wyraził zdziwienie, że komentarze R. Heidensteina są wiązane ze sprawą Zborowskich. I zgodnie z prawdą stwierdził, że przecież ani o ścięciu Samuela, ani o sądzie nad Krzysztofem w nich nie wspomniano. Następnie wywodził, że jeśli o pozostałych członkach ich rodu ,jaką wzmiankę czynią, tedy uczciwą i z sławą ich wspominają". Wskazał przy tym konkretne fragmenty, gdzie są informacje o zasługach Jana Zborowskiego, kasztelana gnieźnieńskiego, który w pierwszych latach panowania Batorego był również hetmanem nadwornym. Później rozważał, dlaczego „wywołać je chca”, i nie znajdował powodów do tego. Przeciwnie, uważał, że „nie zagubienia ale zachowania są godne, gdyż ku sławie narodu naszego napisane są i [...] nie z lekkomyślności jakiej, ale za wolą i rozkazaniem Króla JM nieboszczyka są wydane”. Czynił zarzut adwersarzom, że chcą dzieło proskrybować bez wcześniejszego poddania krytycznej ocenie. Co łatwo uczynić, traktuje ono bowiem o rzeczach niedawnych i ,rycerskim ludziom” znanym. A gdyby zostały stwierdzone pomyłki bądź pominięcia, istnieje możliwość napisania tekstu polemicznego przez innego autora, bądź opublikowania drugiej, poprawionej edycji „Rainoldowych komentarzy”. Tym bardziej iż są jedynie komentarzami, a nie „historią zupełną". W końcu przekonywał, że konfiskata druku jest nieskutecz-

\footnotetext{
7 „Pacyfikacja między Jego M panem Canclerzem a Zborowskimi na convocatiej w Warszawie uczyniona", AGAD, Archiwum Publiczne Potockich 6, s. 164-166.

8 Archiwum Jana Zamoyskiego, t. IV: 1585-1588, wyd. K. Lepszy, Kraków 1948, s. $312-326$.
} 
nym sposobem na ,zatłumienie” przekazu w nim zawartego. Przytaczał przykłady ze starożytnego Rzymu świadczące, iż działania represyjne jeszcze bardziej wzmagały zainteresowania tekstem, powodując powstanie „obiegu podziemnego”. Tym bardziej nie dałyby nic obecnie, gdy wiele jego egzemplarzy znajduje się „u obcych narodów”.

Sprawa dzieła R. Heidensteina kilkakrotnie stawała na porządku obrad sejmu elekcyjnego $1587 \mathrm{r}$. Mimo że był to chyba najbardziej dynamiczny (wielokrotnie zmieniał miejsce obrad) i dramatyczny ${ }^{10}$ ze wszystkich tego rodzaju zgromadzeń w dziejach I Rzeczypospolitej. Kwestia ta oczywiście nie była traktowana indywidualnie, ale wymieniana jako jedna $z$ egzorbitancji. Co ciekawe, znalazła się w spisach egzorbitancji sporządzonych przez komisje powołane w antagonistycznych kołach ${ }^{11}$ do opracowania projektu naprawy tego, „co się skaziło”. Przy czym w kole „prokonwokacyjnym” uznano fakt wydania De bello Moschovitico... za naruszenie szlacheckich wolności. Natomiast członkowie komisji złożonej ze stronników kanclerza byli zdania, iż to dążenie do „wywołania” komentarzy stanowi naruszenie prawa pospolitego ${ }^{12}$.

Ostatecznie odnośnie interesującej nas księgi nic nie postanowiono. Jedynym efektem sejmu elekcyjnego było proklamowanie dwóch elektów, którzy nie zostali uznani przez największą liczbę uczestników zgromadzenia na polach między Warszawą a Wolą. A to doprowadziło do walki zbrojnej o tron, który, dzięki faktom dokonanym, w tym zwycięstwu Jana Zamoyskiego nad arcyksięciem Maksymilianem i jego zwolennikami, objął Zygmunt III Waza. Rozstrzygnięcie to sprawiło, że już nikt więcej z żądaniem konfiskaty dzieła Heidensteina nie występował.

Wydaje się jednak, iż przedstawiony wyżej epizod miał wyjątkowo poważne konsekwencje kulturowe. Mógł bowiem wpłynąć na zaprzesta-

9 Tamże, s. 317-319.

10 Na polu elekcyjnym doszło do śmiertelnego postrzelenia, spalono szopę senatorską, dwukrotnie po kilka tysięcy wojsk sprowadzonych Narwi przez największych potentatów z obu zwalczających się ugrupowań stawało w szyku bojowym - zob. A. Pieńkowska, dz. cyt., s. 285-300.

11 Już w pierwszym tygodniu obrad doszło do podziału wśród zgromadzonych stronnicy Jana Zamoyskiego dokonali secesji, tworząc tzw. „koło czarne”. Niemniej zdecydowana większość zgromadzonych, aprobująca uchwały konwokacji, kontynuowała obrady w tzw. okopie na elekcję przygotowanym. Dlatego koło to nazywano ,prokonwokacyjnym” lub „okopowym”. Próby zgromadzenia wszystkich elektorów w jednym miejscu nie powiodły się i ostatecznie, choć po poważnych zmianach osobowych, w „,kole czarnym” nastapił wybór królewicza szwedzkiego Zygmunta Wazy, a w bardzo uszczuplonym ,prokonwokacyjnym” - arcyksięcia Maksymiliana Habsburga.

12 Dyjaryjusze sejmowe R. 1587. Sejm konwokacyjny i elekcyjny, wyd. A. Sokołowski, Scriptores rerum polonicarum, t. XI, Kraków 1887, s. 62, 68-69, 161-162; BJ, rps. 107, k. 725. 
nie przez rządzących rozwijania dziejopisarstwa oficjalnego, podstawowego instrumentu ,polityki historycznej” prowadzonej przez ówczesne państwa. Henryk Barycz dość wnikliwie przedstawił i bardzo pozytywnie ocenił zabiegi Stefana Batorego i wspierającego go Jana Zamoyskiego mające na celu stworzenie „dworskiej historiografii batoriańskiej”" Słusznie zauważył, że sprawa ta ,nie stanowiła jakiegoś marginesu działania obydwu mężów stanu, lecz była dla nich zasadniczym zagadnieniem polityki nie tylko kulturalnej, ale państwowej w szerszym znaczeniu"14. Teza ta nie doczekał się jednak rozwinięcia. A to właśnie sposób wprzęgania „dziejopisarstwa” do realizacji wewnętrznych celów politycznych wyznaczonych przez króla Stefana i jego kanclerza, uzewnętrznił się w sporze o dzieło Heidensteina prowadzone w czasie bezkrólewia po śmierci Batorego. Dlatego należy kwestię tę nieco rozwinąć.

Stefan Batory, osiagnąwszy tron polski, szybko zorientował się, że jeśliby miał panować zgodnie zasadami ustrojowymi, pozostałby najistotniejszym wprawdzie, ale tylko urzędnikiem Rzeczypospolitej. On zaś, jak większość władców owej epoki, pragnął stać się suwerenem. I podjął w tym kierunku działania, korzystając $\mathrm{z}$ rad i pomocy najzdolniejszego polityka okresu staropolskiego, jakim był Jan Zamoyski. Król zamierzał budować swą pozycję przede wszystkim dzięki sukcesom militarnym i dyplomatycznym. Zamoyski tworzył zaplecze wewnętrzne w postaci silnie związanego z dworem ugrupowania politycznego, skupiającego wiernych i rzutkich ludzi, zdolnych do skutecznych działań w różnych instytucjach życia publicznego. Jednocześnie uważał za niezbędne zdezintegrowanie nadal wciąż silnego ruchu obywatelskiego szlachty, który w głównej mierze przyczynił się do ukształtowania ustroju RP i uznawał się za jego najbardziej gorliwego obrońcę. Dzięki odpowiedniej polityce nominacyjnej i rozdawnictwu królewszczyzn pozyskano część przywódców szlacheckich. Ale też wielką rolę kanclerz przywiązywał do akcji propagandowej. Uważał, że ogół szlachty należy utrzymywać w przekonaniu, iż ustrój Rzeczypospolitej generalnie jest wspaniały. A także, że władca nie dąży do jego zmiany, a jedynie do zwiększenia skuteczności instytucji odpowiedzialnych za obronę państwa i egzekwowanie prawa. Przede wszystkim zaś starał się uzależniać w pierwszej kolejności regalistów, a w następnej - także szlachtę mniej uświadomioną od oficjalnego informowania o sprawach międzynarodowych i wewnętrznych, eksponując przy tym to, co oddziałuje na emocje, a tym samym osłabia zdolność do krytycznej oceny sytuacji.

13 H. Barycz, Szlakami dziejopisarstwa staropolskiego. Studia nad historiografia w. XVI-XVIII, Wrocław 1981, s. 45-64.

14 Tamże, s. 45. 
Największą skuteczność w realizacji takich zamierzeń można było osiagnąć w czasie zwycięskich kampanii wojennych. A zdobywanie dóbr materialnych (w tym nowych terytoriów) i sławy było właśnie celem króla Stefana, a jednocześnie środkiem do wzmocnienia władzy monarszej w Rzeczypospolitej. Batory okazał się przy tym wybitnym wodzem, który pozyskiwał uczestników swych wypraw nie tylko prowadzeniem do sukcesów militarnych ale także dzieleniem trudów swych żołnierzy oraz dbałością o nich na polu walki i o nagradzanie ich zasług po zakończeniu działań. Królowi starał się dotrzymywać kroku również w tej dziedzinie Jan Zamoyski, w 1581 r. mianowany hetmanem wielkim koronnym. Nie mogło więc dziwić, że wśród podkomendnych rosło uwielbienie dla obu.

Przed władcą i najbliższym jego współpracownikiem stał bardzo trudny problem uzyskania choćby w części takiego uznania wśród szlacheckich mas, ceniących przecież pokój i prowadzących ziemiańsko-obywatelski styl życia. Do odradzania idei szlachcica-rycerza, do budzenia „Marsa sarmackiego" starali się oni pozyskiwać najwybitniejszych ówczesnych poetów. Jednak zgodnie z duchem epoki postanowili oddziaływać przede wszystkim za pomocą narracji historiograficznej. Wszak wtedy wielkim uznaniem cieszyła się maksyma, iż „historia jest mistrzynią życia”, a Jan Zamoyski doskonale wiedział, że wielu jego rodaków para się spisywaniem różnego rodzaju „ksiag pamiętniczych”. W tym tkwiło jednak pewne zagrożenie dla planów powołania ośrodka oficjalnych, kontrolowanych przez rządzących, „studiów historiograficznych”.

O trudnościach ze zorganizowaniem takiego ośrodka pisał wyczerpująco Henryk Barycz: „Polska wchodziła w fazę wielkiego rozkwitu dziejopisarstwa, ale była to historiografia niekontrolowana, związana ideowo z obozem demokracji szlacheckiej. W tych warunkach niełatwo było znaleźć dziejopisa, który podjałby się odtworzenia rozwoju dziejowego Polski w duchu i pod dyktando batoriańskiej ideologii silnych rządów, który by miał dostateczny autorytet, aby przeciwstawić się w odtwarzanej panoramie dziejowej Polski tendencjom parlamentarno-szlacheckim, ograniczającym nadrzędną rolę władcy"15.

Pierwsi nadworni dziejopisowie Batorego: Wenecjanin Gianmichele Brutus i Siedmiogrodzianin Franciszek Forgach pracowali przede wszystkim nad historią Węgier. Zawiódł natomiast zupełnie oczekiwania króla i kanclerza jako dworski twórca dziejów Polski - Stanisław Sarnicki. Od $1582 \mathrm{r}$. w roli oficjalnego historiografa dworu odpowiedzialnego za prace

15 H. Barycz, dz. cyt., s. 51. 
nad najnowszą przeszłością Rzeczypospolitej występował sekretarz królewski Reinhold Heidenstein. Wykształcony członek szlacheckiego rodu osiadłego w Prusach Książęcych, a pochodzącego z Frankonii, posiadający wielkie zdolności i pewne doświadczenie dziejopisarskie ${ }^{16}$, podjął się trudnego zadania konstruowania narracji o wydarzeniach dotyczących kraju, o którym w początkowym okresie swej działalności niezbyt wiele wiedział. Bez cienia watpliwości realizował koncepcje prac nakreślonych przez kanclerza na podstawie materiałów źródłowych i relacji dostarczanych przez niego. Ostateczna redakcja była również przez Zamoyskiego „doglądana” i za przyzwoleniem króla oddawana do druku.

Można więc mieć watpliwości, kogo uznać za twórcę interesującego nas dzieła, które formalnie ukazało się pod nazwiskiem Heidensteina $^{17}$, a miało budzić podziw wobec króla, a także hetmana koronnego ze względu na ich wojenne dokonania. Miał to być jedyny szerszy przekaz dostępny na rynku księgarskim poza uniwersałami tłoczonymi w drukarni polowej, która towarzyszyła wojskom królewskim, informującym na bieżąco o zdobywanych zamkach i opanowywanych terytoriach. Już w trakcie pierwszej kampanii przeciwko Moskwie (27 VII 1579 r.) król pod groźbą kary śmierci zabronił jej uczestnikom zamieszczania informacji o sprawach związanych z działaniami wojskowymi w listach pisanych podczas marszu i w trakcie walk. Po zakończeniu sejmu 1580 r., który uchwalił podatki na kontynuowanie działań wojennych, władca poszedł jeszcze dalej. Uniwersałem $\mathrm{z}$ dnia 7 lutego tego roku wprowadził cenzure druków dotyczących tej wojny, jak i wszystkich dzieł historycznych ${ }^{18}$. Odtąd drukarze mogli wydawać książki z tej dziedziny tylko zaaprobowane przez władcę.

De bello Moschovitico commentariorum libri VI było pierwszą praca poświęconą dziejom najnowszym, która powstała według głęboko przemyślanych przez króla i kanclerza założeń, wykonaną wyjątkowo starannie i wydaną w oficynie Łazarzowej, wówczas uznawanej za najlepszą. To Batory i Zamoyski postanowili, że będzie miała formę naśladującą Komentarze Cezara. Wyrażała się w tym swoista asekuracja. Można było bowiem w przypadku krytyki tłumaczyć, jak uczynił to podczas bezkrólewia w 1587 r. kanclerz, że tak zatytułowany tekst nie aspiruje do ostatecznego, całościowego ujęcia opisywanego wydarzenia. A także po-

${ }_{16}$ Opracował dzieje nacji niemieckiej na uniwersytecie w Padwie.

17 Zob. S. Łempicki, Śladem „, Komentarzy” Cezara, [w:] tegoż, Renesans i humanizm w Polsce, Warszawa 1952, s. 19-20; B. Kocowski, Trzej padewczycy. Wpływy Batorego i Zamoyskiego na działalność R. Heidensteina, Lwów 1939, s.42-47.

18 Akta Metryki Koronnej co ważniejsze z czasów Stefana Batorego. 1576-1586, zebrał i oprac. A. Pawiński, Źródła dziejowe, t. XI, Warszawa 1882, s. 122-123. 
zwolić na bardziej jednostronne interpretacje i oceny faktów. Rządzący, mając świadomość, że tylko taki przekaz będzie dostępny na rynku księgarskim, mogli liczyć, iż spełni oczekiwaną rolę w budowaniu apoteozy króla i hetmana oraz $\mathrm{w}$ sławieniu dzielnego rycerstwa zwłaszcza $\mathrm{z}$ rot przyjaciół pana na Zamościu i rodaków Batorego.

W 1584 r. książka była już gotowa, może nawet została wytłoczona. Świadczy o tym data na stronie tytułowej i znana Baryczowi korespondencja między humanistami krakowskimi i wrocławskimi ${ }^{19}$. Jednak w 1584 r. miały miejsce w Rzeczypospolitej dramatyczne wydarzenia. Najpierw pojmanie na terenie starostwa krakowskiego i ścięcie z rozkazu miejscowego starosty, którym był Jan Zamoyski, banity Samuela Zborowskiego, a następnie oskarżenie o spiskowanie przeciwko władcy i pozwanie przed sąd sejmowy kolejnych dwóch członków rodu Zborowskich, wciąż wielce popularnego wśród szlachty. Zmarł też Iwan Groźny. I te zapewne sprawy były powodem wstrzymania rozpowszechniania druku. A po burzliwym sejmie 1585 roku $^{20}$ był on jeszcze poddawany przeglądaniu przez A. Possevina ${ }^{21}$ i Jana Zamoyskiego, który dokonywał w kwietniu 1585 r. ostatecznej ,poprawy kommentarzów"22. Edycja została sfinalizowana u progu jesieni i w ostatnich miesiącach tego roku była rozsyłana do zagranicznych uczonych i agentów dyplomatycznych państw europejskich.

Nie wiemy, jaki był odbiór tego dzieła za życia króla Stefana. Z przywoływanej w pierwszej części artykułu Odpowiedzi ... Zamoyskiego wiadomo, że do wiosny 1587 r. nie opublikowano jakichkolwiek replik. Wywołał natomiast zainteresowanie „obcych”. A zdaniem H. Barycza zostały bardzo życzliwie przyjęte w kręgach intelektualistów zagranicznych.

Śmierć Batorego i przedstawiona wyżej sprawa „Komentarzy Reinoldowych", którymi zajmowały się sejmy w czasie bezkrólewia w 1587 roku miały wpływ zarówno na dalsze losy tej konkretnej księgi, a co jeszcze ważniejsze, również na dalszy rozwój dziejopisarstwa staropolskiego, a w pewnej mierze może i naszej historiografii w wiekach późniejszych.

19 H. Barycz, dz. cyt., s. 61-62.

20 Zob. E. Dubas-Urwanowicz, O nowy ksztalt Rzeczypospolitej. Kryzys polityczny w państwie w latach 1576-1586, Warszawa 2013, s. 122-151.

21 Jako uznanego dyplomatę-eksperta od spraw moskiewski, autora Moscovi.

22 J. Zamoyski do Piotra Tylickiego z 8 IV 1585 r., Archiwum Jana Zamoyskiego, t. IV, s. 21. List ten przynosi też informacje dotyczące udziału kanclerza w kolejnym dziele dziejopisarskim, które miało być sygnowane przez R. Heidensteina: ,jednym impetem dy k t o w a ć bę dę i te dwie lecie po wojnie. Które będą mogły, b ę d z i e li się zdało, poleżyć, ale za świ e ż e le pi ej je naterminować. Co sprawiwszy Reinolda poślę tam do Krakowa i zaraz druku będzie mogł dojrzeć. Interim o jurgielt staraj mu się WM" - podkreślenia JD. 
Problem wymaga badań i na pogłębione wyjaśnienie zasługuje. Poniższe uwagi sa jedynie bardzo wstępnymi hipotezami o charakterze prowokujacym.

De bello Moschovitico... w I Rzeczypospolitej nie miało już żadnych wznowień, chociaż poza jej granicami tylko w XVI stuleciu ukazały się trzy edycje łacińskie, a w 1592 r. również w języku niemieckim. Najpoważniejsze z dzieł Heidensteina: Rerum Polonicarum ab excessu Sigismundi Augusti libri XII zostało wydane ponad pół wieku po śmierci dziejopisa, także poza granicami naszego kraju. Natomiast napisana przez niego biografia Jana Zamoyskiego ukazała się dopiero w XIX w. Prace innych dziejopisów ze schyłku XVI i pierwszej połowy XVII wieku w zdecydowanej większości drukowane były również po wielu dziesięcioleciach od opisywanych w nich wydarzeniach. Zwłaszcza jeśli ich autorzy przedstawiali wyważone ujęcia przedstawianych wydarzeń.

Wskazuje to niepowodzenie pomysłu króla Stefana i jego kanclerza dotyczącego kształtowania pożądanych dla nich postaw szlachty przez pisma nadwornych „historiografów” i przy stosowaniu cenzury prewencyjnej, czyli zgodnie z praktyką stosowaną wówczas w krajach europejskich. Działania cenzorskie odnośnie druków poświęconych historii w czasach panowania Wazów, odnotowane przez Paulinę Buchwald-Pelcowa, wskazują na odosobnione i mało skuteczne przypadki zastosowania cenzury represyjnej ${ }^{23}$.

Uznanie faktu wydania w czasie obowiązywania cenzury prewencyjnej dzieła Heidenstaina przez większość uczestników sejmu konwokacyjnego i znaczą część obecnych na sejmie elekcyjnym za naruszenie wolności szlacheckiej wzmogło nieufność członków tego stanu wobec wszelkich tekstów drukowanych. Uznawano je za propagandowe, a więc niewiarygodne. Takie nastawienie szlachty jako zjawisko wręcz powszechne w czasach panowania Zygmunta III, stwierdziła Urszula Augustyniak w bardzo ważnym studium na temat informacji i propagandy ${ }^{24}$. Zaczął się w kulturze szlacheckiej nawrót do tekstów rękopiśmiennych, które poczęły dominować w życiu publicznym jako instrument kształtowania świadomości społecznej, w tym i historycznej. Anonimowe pisma ulotne pozwalały na bezkarne rzucanie pomówień także przeciw monarsze, czego boleśnie doświadczył Zygmunt III Waza, szczególnie w latach 15891592 i w czasie rokoszu Zebrzydowskiego. W pierwszym okresie prym w skutecznym stosowaniu tego środka walki politycznej wiódł oczywi-

23 P. Buchwald-Pelcowa, dz. cyt., s. 45-48.

24 U. Augustyniak, Informacja i propaganda w Polsce za Zygmunta III, Warszawa 1981, passim. 
ście Jan Zamoyski, w drugim jego wychowankowie. Kanclerz, gdy nie powiodły mu się starania, by doprowadzić do opuszczenia Rzeczypospolitej przez Zygmunta III, ani też do narzucenia królowi swej woli, podjął z nim bezpardonową walkę. Pisma zawierające oskarżenia o „kupczenie korona" i gardzenie naszym krajem, czyli o tajne układy z Habsburgami w sprawie przekazania im tronu polskiego; o fanatyzm religijny, o czym świadczyć miało nieprzerwanie gry w piłkę, gdy niszczony był nieopodal Wawelu zbór ewangelicki etc., miały charakter sensacyjny.

\section{Streszczenie}

\section{Dzieło dziejopisarskie przedmiotem debaty sejmów w czasie trzeciego bezkrólewia}

Artykuł poświęcony jest reakcji szlachty uczestniczącej w sejmach okresu bezkrólewia po śmierci Stefana Batorego na druk poświęcony ówczesnym dziejom najnowszym: De bello Moschovitico commentariorum libri VI autorstwa Reinholda Heidensteina. Było to dzieło dziejopisarstwa oficjalnego przygotowane przy osobistym zaangażowaniu kanclerza koronnego, które po wprowadzeniu cenzury prewencyjnej miało, zdaniem opozycji, narzucać opinii publicznej wizję przeszłości korzystną dla rządzących, a więc stronniczą. To wyjątkowe w dziejach I RP wydarzenie jakkolwiek nie doprowadziło do konfiskaty książki, gdyż rzecznicy tego rozwiązania nie zdołali zapewnić tronu swemu kandydatowi ani też sprawić, że wprowadzenie cenzury na druki historyczne nie zostało uznane za bezprawne, doprowadziło jednak do zaniechania takich praktyk w czasach Zygmunta III. Prawdopodobnie dlatego, że kanclerz Jan Zamoyski, staropolski mistrz gry wizerunkowej, przechodząc do opozycji względem młodego Wazy, uznał, iż znacznie szybciej będzie można manipulować opinią publiczną przy użyciu anonimowych pism ulotnych.

Słowa kluczowe: bezkrólewie z 1587 r. - cenzura - dziejopisarstwo - Heidenstein Reinhold - król Stefan Batory - sejm konwokacyjny i elekcyjny - Zamoyski Jan - Zborowscy. 


\section{Summary}

\section{The Polish Sejm Debating over a Work of History: The Case of 'De bello Moschovitico' by Reinhold Heidenstein, in 1587}

The article deals with the reaction of the Polish nobility, convened during the interregnum after the death of King Stephen Báthory to elect the new monarch, to the book De bello Moschovitico commentariorum libri VI by Reinhold Heidenstein, which treated on recent historical events. Heidensteins work conveyed the official views of the ruling circles, and Chancellor Jan Zamoyski was personally engaged in its preparation. However, the opposition was of the opinion that in combination with preventive censorship the book was supposed to impose upon the public a vision of the past favourable to the governing elite, e.i. a biased one. This episode, exceptional in the history of the Polish-Lithuanian Commonwealth, did not result in the confiscation of the book. The anti-Zamoyski faction failed both to bring about the election of their candidate to the Polish throne, and to persuade the Sejm to delegalize censoring historical works. Nevertheless, the affair resulted in refraining by the ruling circles from such actions during the reign of the next king, Sigismund III Vasa. Most probably, Jan Zamoyski, who soon after the election found himself in opposition to the throne, himself a master of political propaganda, decided that it would be much more effective to manipulate public opinion with anonymous effemeral prints.

Key words: interregnum of 1587 - censorship - historiography - Heidenstein, Reinhold - King Stephen Báthory of Poland - Convocation and Election Sejm Zamoyski, Jan - the Zborowski brothers. 